\title{
Recovery from herpes simplex encephalitis: selective impairment of specific semantic categories with neuroradiological correlation
}

\author{
V PIETRINI,* P NERTEMPI,* A VAGLIA, $\dagger$ M G REVELLO $\S$ V PINNA $\ddagger$ \\ F FERRO-MILONE*
}

From the Department of Neurology, ${ }^{*}$ Division of Infectious Diseases $\dagger$ and Institute of Neuroradiology, $\ddagger$ Vicenza Hospital, Virus Laboratory, Institute of Infectious Diseases,§ University of Pavia, Italy

SUMMARY The clinical, neuropsychological and neuroradiological features of two patients affected by herpes simplex virus type 1 (HSV-1) encephalitis are described. An experimental study for the assessment of naming, recognition and description displayed in one patient a persistent significant impairment in naming living things. The other patient showed a failing "semantic memory" for the same categories, although a significant impairment emerged only for plants. In both patients, the late neuroradiological sequelae were localised mainly in the inferior and middle gyri of the left temporal lobe and in the left-side insula. In one patient, the right-side insula was also involved. The selective cerebral damage induced by HSV-1 is stressed and a correlation between the neuroradiological and neuropsychological findings is attempted. The stereotyped anatomical and neuropsychological changes lead to the belief that the virus may recognise, within the limbic system, particular cellular "strains" on the basis of their molecular specificity.

Encephalitis caused by type 1 herpes simplex virus (HSV-1) is still a severe disorder, although its mortality rate has dropped from about $70 \%$ with placebo or inefficacious drug therapy ${ }^{12}$ to about $40 \%$ with vidarabin $^{3}$ and about $20 \%$ with acyclovir. ${ }^{4}$ As a result, an increasing number of patients now recover from the disease but are left with neurological sequelae ranging from severe dementia with markedly disturbed behaviour to mild impairment of memory and speech. Occasionally, however, some patients do appear to recover completely.

The two patients reported here had an excellent recovery of the higher cortical functions, although anomia in one case and an impairment of semantic memory in the other persisted. In both cases the sequelae involved such semantic categories as animals and plants.

Categorisation and, consequently, the formation of "concepts" is one of the primary cognitive processes in man. Concepts play an important role in cognitive processes, as they allow humans to deal with objects

Address for reprint requests: Dr Vladimiro Pietrini, Department of Neurology, "San Bortolo" Hospital, 36100 Vicenza, Italy.

Received 9 October 1987 and in revised form 5 April 1988. Accepted 11 April 1988 and events even when there is no concrete referent for them. Concepts are "stored" and can be "retrieved" and "expressed" as part of an organisation which is based on semantic categories, or general concepts.

It is not our purpose to discuss philosophical and psychological principles underlying the organisation of categories. We merely point out that selective deficits for certain semantic categories have been reported in some patients without all other categories being affected as a result. The first study conducted on a large series of 135 aphasic patients ${ }^{5}$ showed a high incidence of dissociation for six semantic categories, namely body parts, actions, objects, colours, letters, and numbers. In the last 10 years, category deficits have been studied extensively by Warrington and Shallice, who based their investigations on the analysis of a few cases of spontaneous pathology in humans. A dual dissociation was then evidenced between the "abstract" and the "concrete" category $^{6-8}$ and between those of "animate" vs. "inanimate" objects. ${ }^{89}$

It appears from the literature that distinct cerebral structures are responsible for retaining and expressing specific categories, but it is not yet known which structures these are.

The purpose of our study was to investigate how the selective neuropsychological impairment of the cate- 
gories of animals and plants evolved over time in our patients and to evaluate the corresponding anatomical damage by neuroradiological techniques.

\section{Patients and methods}

Case No. 1 R.M., a 23 year old man and a manager in his father's company was admitted to the infectious disease ward after a 5 day history of erratic fever up to $40^{\circ} \mathrm{C}$ and severe frontal headache accompanied by disturbed behaviour and speech impairment. Upon admission the patient was found to suffer from confusion, disorientation, and global aphasia. The EEG recording showed diffuse abnormalities prevailing in the left temporal region with pseudoperiodic slow waves. A CSF test revealed an increased number of cells, mostly lymphocytes $\left(73 \mathrm{~mm}^{3}\right)$. On that same day treatment with acyclovir was started. No changes in density were apparent on CT. The 11th day after the onset the patient suffered from a generalised seizure. A second EEG recording showed more extensive focal abnormalities in the left frontal and temporal regions. Further CT revealed a large area of low density in the left temporal region extending to the ipsilateral frontobasal region. The clinical conditions, as well as the EEG and CT findings, improved gradually over the following days. The patient was discharged from hospital 30 days later in good general condition, except for mild signs of amnesia and anomia. After a few months, he was able to resume work at his father's company with good effect.

Case no. 2 J.V., a 47 year old man and a manufacturer of custom-made spectacles began to show confusion and global aphasia after 3 days with $38.5^{\circ} \mathrm{C}$ fever and general discomfort. The next day he developed tonic-clonic status epilepticus. Upon admission, the patient was in a deep coma. A lumbar puncture revealed blood traces in the CSF. CT showed that the left lateral ventricle was compressed anteriorly, with an area of hypodensity around a hyperdense focus in the insula of the left temporal region which remained unaltered after contrast medium enhancement. The EEG recording showed diffuse slowing of the background rhythms with three phase pseudoperiodic slow spikes in the left hemisphere. Treatment with acyclovir was started on the day of admission. The patient's clinical picture worsened over the following days because of respiratory insufficiency and he was put on a mechanical respirator. Further CT revealed a large area of low density involving the left median and basal temporal region and extending to the ipsilateral frontal region. After a week the patient began to improve slowly, and eventually regained consciousness and recovered his respiratory function. When he was discharged from hospital 30 days later, he was in good general condition with only moderate amnesia as neurological sequela. After a few months he successfully resumed work and his technical and entrepreneurial skills proved to be as good as before the disease.

\section{Virological tests}

The following parameters were determined and considered in assessing viral diagnosis of herpes simplex encephalitis: (1) HSV-1 specific IgG antibody titre in sequential serum and CSF paired samples taken simultaneously from the two patients (six paired samples for the patient R.M., and four for the patient J.V.). HSV-1 specific IgG was determined by using an enzyme linked immunosorbent assay (ELISA) and testing two-fold dilutions of serum and CSF samples. A ratio $\leqslant 20$ between serum and CSF HSV-1 specific antibody titre was considered significant for herpes simplex encephalitis. Measles specific IgG were determined in the same CSF and serum samples by using the ELISA technique with measles antigen bound to the solid phase. ${ }^{(2)}$ Serum and albumin concentration; ${ }^{(3)}$ the Link index for intrathecal production of IgG. ${ }^{10}$

\section{Neuroradiological investigation}

Seven CT examinations were made on the first patient, including four in the acute stage of the disease, one during the second month, one after a year and a half. MRI was done 19 months after onset of symptoms. Six CT examinations were made on the second patient, including three in the acute stage, one at 6 months and the last after a year. MRI was done 13 months after onset of symptoms. All CT was performed on the Siretom 2000 cranial scanner or the Somaton DR body scanner (Siemens). MRI was done using a resistive 0.15 Tesla system and a superconductive 0.5 Tesla system (Gyroscan $R$ and Gyroscan 55-Philips). Relative T1-weighted and T2-weighted spin-echo (SE) sequences were obtained in both patients. Scans were performed in three spatial dimensions (axial, coronal and sagittal scans).

\section{Neuropsychological testing}

Upon discharge, both patients were tested for apraxia, agnosia, aphasia and amnesia. The first patient was later submitted to four neuropsychological tests in the following order: WAIS at 3 months from discharge; WAIS, WechslerMemory and a speech test at 6 months; an experimental test (testing word retrieval and word comprehension) at 1 year; WAIS, Wechsler-Memory and the experimental test at 18 months. The second patient was submitted to three successive neuropsychological tests: WA1S, Wechsler-Memory and the experimental test at 6 months from discharge; the experimental test at 1 year; WAIS Wechsler-Memory and experimental test at 18 months.

The experimental test consisted of four tests for each patient aimed at assessing their abilities to name, recognise and describe pictures and names belonging to the categories of inanimate objects, animals, and plants. Ninety colour pictures, that is, $\mathbf{3 0}$ for each category, were used as stimuli, chosen in such a way that: (a) they were unambiguous; (b) they were of common occurrence; and, (c) they represented concepts at a basic level of categorisation. ${ }^{11}$

Test 1 Picture naming - Without setting any time limit, the patient was asked to name the items presented individually in a random order. In this and the following tests each correct answer scored one point.

Test 2 Word/Picture Matching-The patient was asked to recognise an object, animal or plant named by the examiner among five items of the same category presented to him in a random order.

Test 3 Word Definition-The patient was asked to describe as accurately as possible the objects, animals and plants named individually by the examiner in a random order.

Test 4 Naming from Description-The patient was asked to name the concepts characterising the items verbally presented by the examiner, who provided, for each one of 
them, one superordinate category of first level, one of second level, and three attributes, for example animal; mammal; domesticated; hairy; barking (expected answer: dog).

Ten normal subjects matched to our patients for age, sex and level of education were used as a control group and were submitted to the same tests. Statistical analysis of the results included: (1) a Z-score analysis, in order to compare the performances between the patients and controls and, (2) a chi-square test, in order to check the patients' performances in each single test and determine whether their deficits involved specific categories.

\section{Results}

Virological tests Viral diagnosis of herpes simplex encephalitis was assessed retrospectively in the two patients by means of serological techniques. Results of virus specific IgG and non-specific immunological parameters are shown in table 1 . Reported data show that serum/CSF HSV-1 specific antibody ratios were consistently $\leqslant 20$ in all the sequential serum and CSF paired samples examined from the two patients, concomitantly with ratio values $\geqslant 100$ for measles specific antibody determined in the same serum and CSF samples. Damage of the blood-brain barrier of a discrete kind was demonstrated in patient J.V. by the serum/CSF albumin ratio values, close to the onset of symptoms. The Link index, however, was virtually always significant for intrathecal IgG synthesis in the sequential samples examined from both patients. Finally, the determination of HSV-1 specific IgG antibody showed that patient R.M. was suffering from a primary herpes simplex infection, whereas a recurrent herpes simplex infection was present in patient J.V. Neuroradiological investigation: The CT findings in the acute stage were similar to those reported in the literature and regarded as typical of the disease. ${ }^{12-14}$ Figure 1 shows the sequential evolution of the left temporal lesions in both patients. The aim of the neuroradiological study was to investigate the topography of late radiological sequelae and to compare them with the neuropsychological damage over the same period of time. For this purpose we analysed in detail the CT and MRI findings of our patients at 18 months (Case 1) and 1 year (Case 2) from discharge.

Case 1 Changes in the cerebral parenchyma were found in two-thirds of the left anterior temporal region and in the superficial cortico-subcortical area of the left-side insula. Another slight change appeared in the left paramedian fronto-basal region. The ventricles were normal and no signs of cortical atrophy were found. A cyst was present in the pineal region. The most affected structures in the left temporal lobe were the inferior temporal gyrus, the hippocampal region and the parahippocampal gyrus. The middle temporal gyrus, especially at the cortex, and the superior temporal gyrus were less damaged. The region of the insula showed changes in density similar to those in the inferior temporal gyrus. All lesions were unilateral (figs 2 and 3).

Case 2 The major lesion was located in the left anterior and middle temporal regions and involved both the cortex and the subcortical white matter extending cranially to the left-side cortex of the insula. A mild involvement was also apparent in the right-side cortex of the insula and in the left paramedian fronto-basal region. The most affected structures in the temporal lobe were the same as those in Case 1 with a greater involvement of the middle temporal gyrus. Mild cortical atrophy, mostly affecting the fronto-temporal region, and slight dilatation of the left lateral ventricle were also present (figs 4 and 5).

Neuropsychological testing: No ideomotor, ideational and constructional apraxia were present at the first examination after discharge. Patients' reading, writing and calculation abilities were normal. The patients' scores on WAIS, Wechsler-Memory and

Table 1 Determination of specific and non-specific immunological parameters on sequential serum and CSF paired samples from the two patients

\begin{tabular}{|c|c|c|c|c|c|c|c|}
\hline \multirow[b]{2}{*}{ Patient } & \multirow{2}{*}{$\begin{array}{l}\text { Days } \\
\text { after } \\
\text { onset }\end{array}$} & \multicolumn{2}{|c|}{$\begin{array}{l}\text { HSV-I-specific IgG } \\
\text { determined by ELISA }\end{array}$} & \multicolumn{2}{|c|}{ Serum/CSF IgG antibody ratio } & \multirow{2}{*}{$\begin{array}{l}\text { Serum/CSF } \\
\text { albumin } \\
\text { ratio } \\
\left(>130^{*}\right)\end{array}$} & \multirow{2}{*}{$\begin{array}{l}\text { Link } \\
\text { index } \\
\left(<0.67^{*}\right)\end{array}$} \\
\hline & & Serum & $C S F$ & $H S V-I$ & Measles & & \\
\hline $\begin{array}{l}\text { R.M. } \\
\text { (Case 1) }\end{array}$ & $\begin{array}{r}5 \\
8 \\
11 \\
15 \\
50 \\
150\end{array}$ & $\begin{array}{r}100 \dagger \\
100 \\
200 \\
4,000 \\
128,000 \\
64,000\end{array}$ & $\begin{array}{r}<50 \\
<50 \\
200 \\
1,600 \\
6,400 \\
6,400\end{array}$ & $\begin{array}{r}- \\
- \\
1.0 \\
2.5 \\
20.0 \\
10.0\end{array}$ & $\begin{aligned}> & 100 \\
& \text { ND } \ddagger \\
> & 100 \\
& N D \\
> & 100 \\
& N D\end{aligned}$ & $\begin{array}{l}125.0 \\
100.0 \\
116.0 \\
148.0 \\
175.0 \\
\text { ND }\end{array}$ & $\begin{array}{l}0.65 \\
0.89 \\
1.13 \\
2.05 \\
2.39 \\
\text { ND }\end{array}$ \\
\hline $\begin{array}{l}\text { J.V. } \\
\text { (Case 2) }\end{array}$ & $\begin{array}{r}4 \\
8 \\
24 \\
29\end{array}$ & $\begin{array}{l}4,000 \\
4,000 \\
4,000 \\
8,000\end{array}$ & $\begin{array}{l}\text { ND } \\
1,000 \\
4,000 \\
6,400\end{array}$ & $\begin{array}{l}- \\
4 \cdot 0 \\
1 \cdot 0 \\
1 \cdot 2\end{array}$ & $\begin{array}{r}\text { ND } \\
\text { ND } \\
>100 \\
>100\end{array}$ & $\begin{array}{r}66 \cdot 3 \\
25 \cdot 0 \\
103 \cdot 0 \\
200 \cdot 0\end{array}$ & $\begin{array}{l}0.53 \\
0.91 \\
1.25 \\
2 \cdot 10\end{array}$ \\
\hline
\end{tabular}

*Normal value.

†Titre expressed as reciprocal of serum dilution.

†Not determined. 


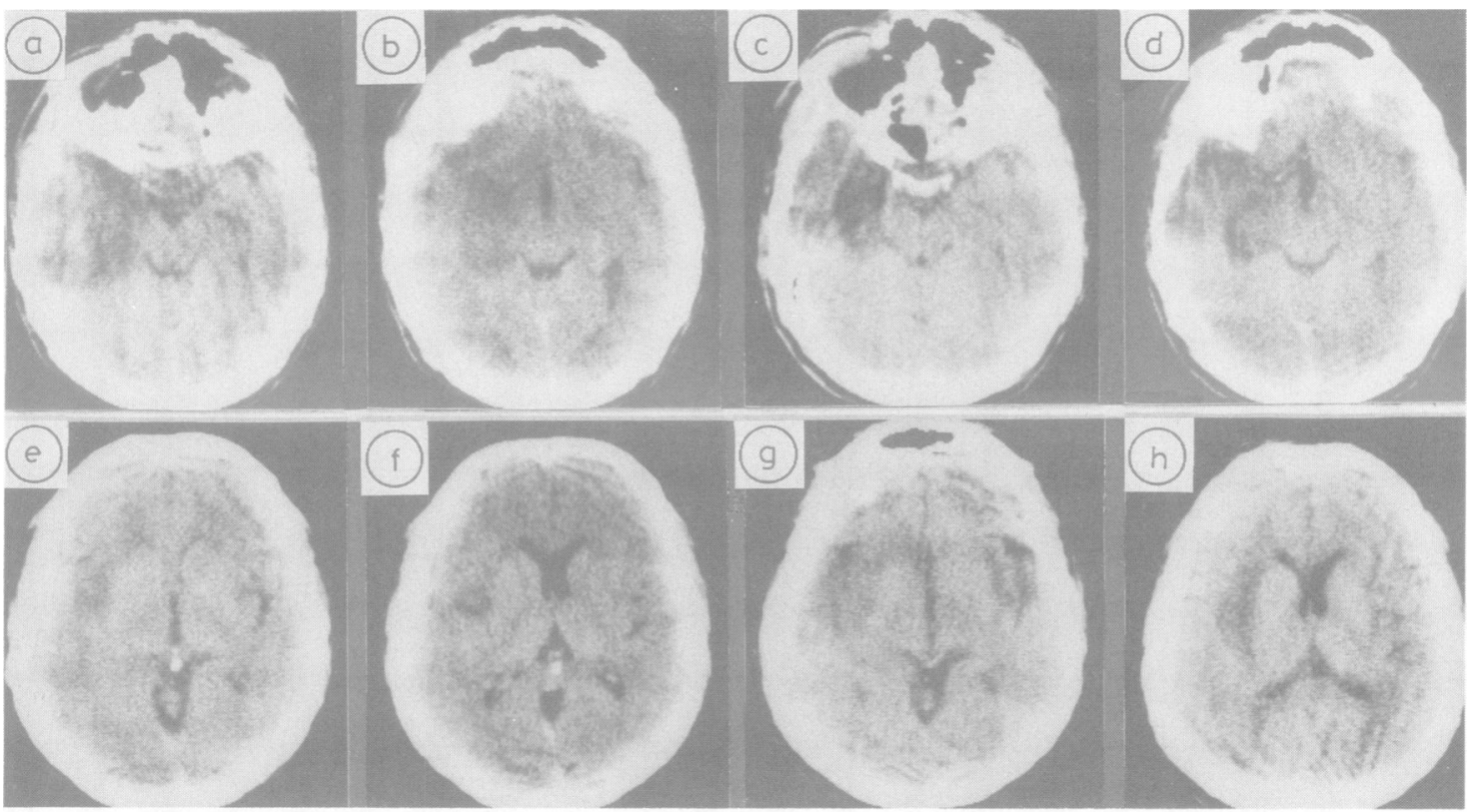

Fig 1 Case $1(a, b, c, d)$ and case $2(e, f, g, h): C T$ showing the evolution of the left temporal lesions in the acute stage.
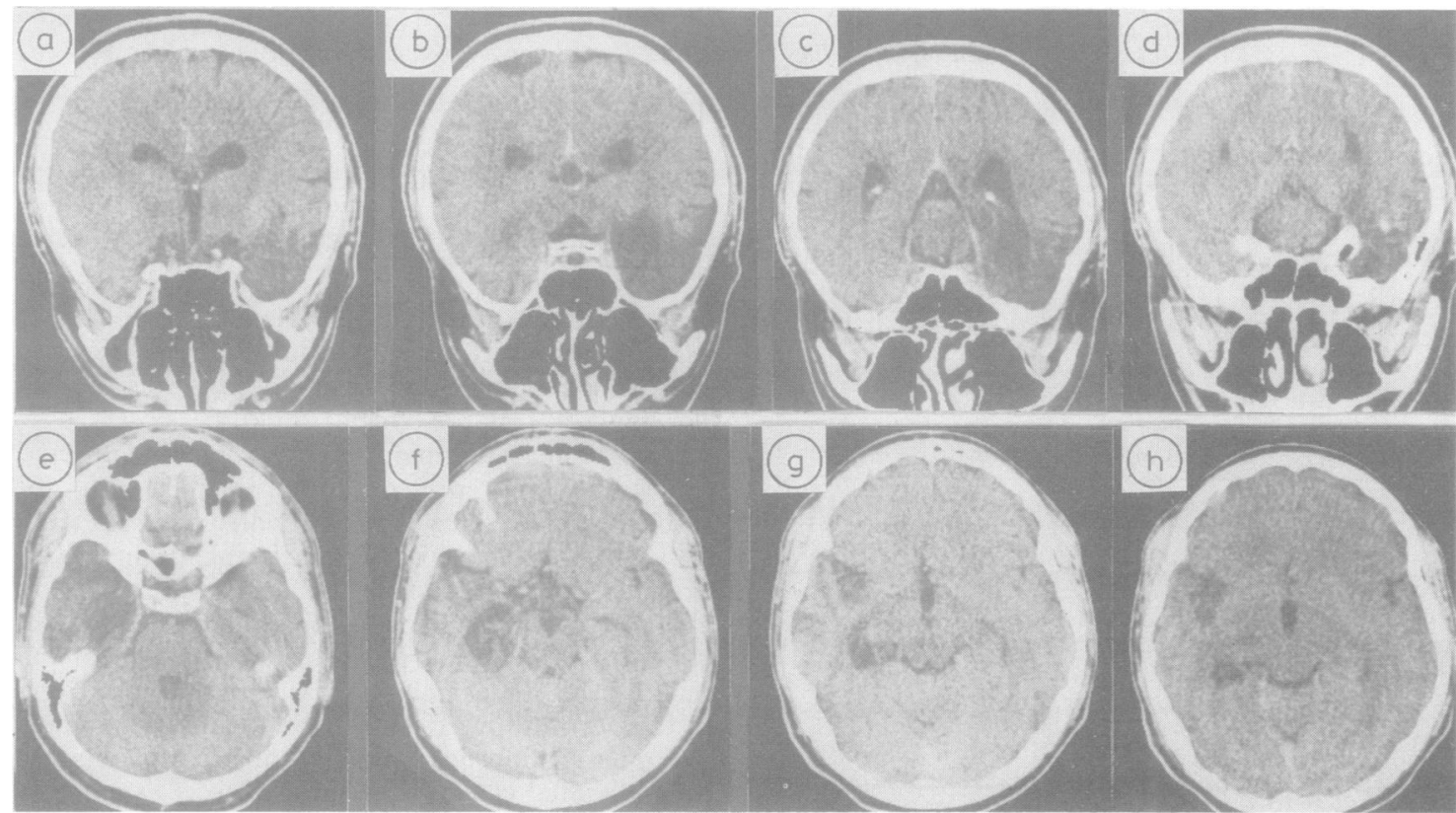

Fig 2 Case 1: Serial CT 18 months after discharge. a-d (coronal sections): low-density lesions in the left inferior and middle temporal region. e-f: marked low-absorption abnormality in the left hippocampus. $g$-h: lesion of the left-side insula. 

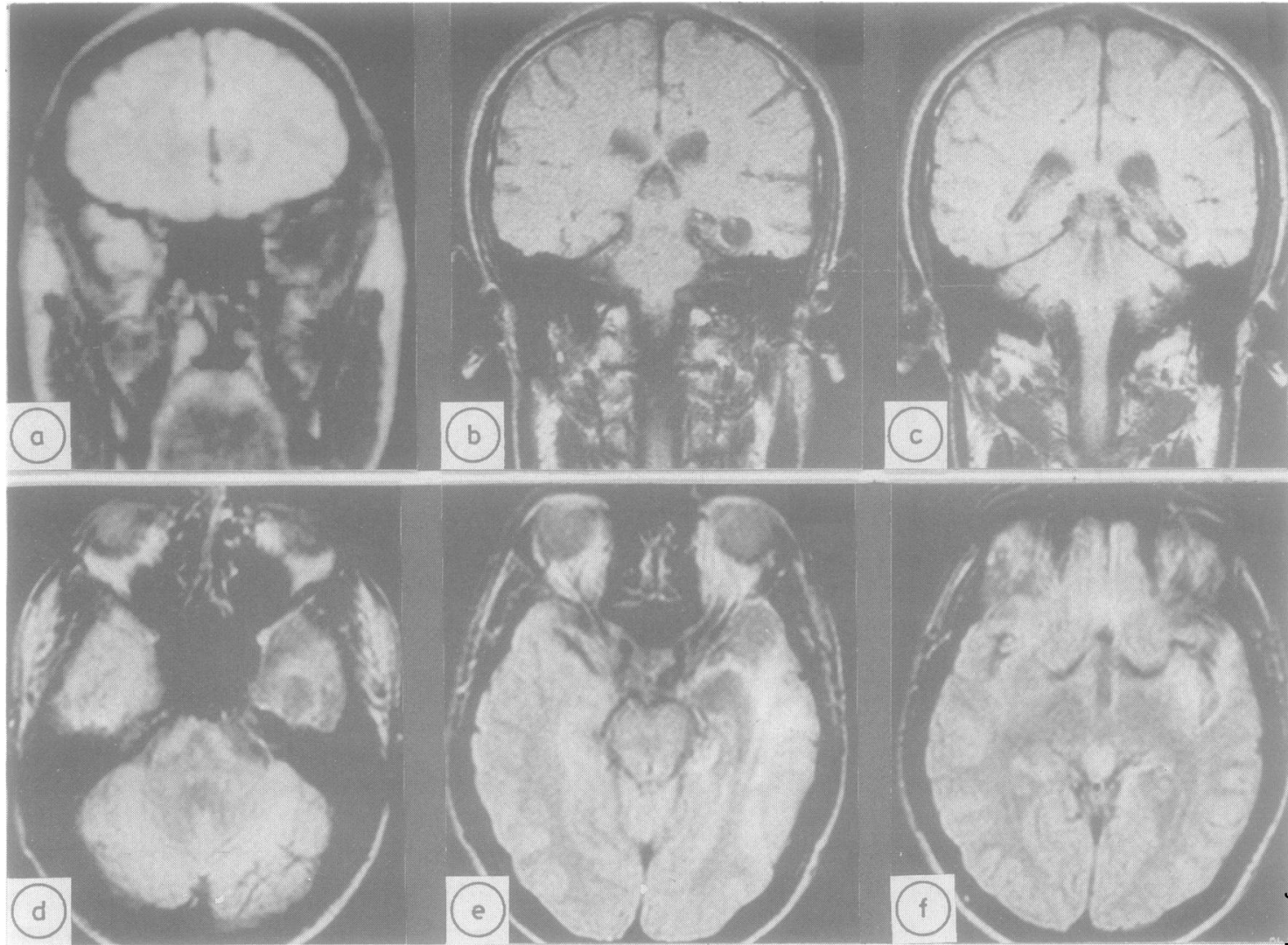

Fig 3 Case 1 MRI: Coronal $(a, b, c)$ and sagittal $(d, e, f)$ sections. Altered signal areas in the left temporal lobe and in the left side insula.

Token test are reported in table 2, which shows that intelligence was restored to medium levels one and a half years later. Severe amnesia persisted in both patients, while no aphasia could be evidenced on the Token test. The presence of sensory deficits, that is visual and auditory, was excluded by clinical and lab-

Table 2 Neuropsychological test

\begin{tabular}{|c|c|c|c|c|c|}
\hline & \multicolumn{5}{|c|}{ Patients' scores on sequential examinations } \\
\hline & \multicolumn{3}{|c|}{ Case I } & \multicolumn{2}{|l|}{ Case 2} \\
\hline & $3^{*}$ & $6^{*}$ & $18^{*}$ & $6^{*}$ & $18^{*}$ \\
\hline $\begin{array}{l}\text { WAIS } \\
\text { FIQ } \\
\text { VIQ } \\
\text { PIQ }\end{array}$ & $\begin{array}{l}79 \\
76 \\
85\end{array}$ & $\begin{array}{l}89 \\
89 \\
91\end{array}$ & $\begin{array}{r}98 \\
94 \\
103\end{array}$ & $\begin{array}{r}90 \\
84 \\
100\end{array}$ & $\begin{array}{r}102 \\
99 \\
106\end{array}$ \\
\hline $\begin{array}{l}\text { Wechsler memory } \\
\mathrm{MQ} \\
T O K E N\end{array}$ & $\begin{array}{l}\text { NT } \\
36 / 36\end{array}$ & 74 & 80 & $\begin{array}{l}70 \\
34 / 36\end{array}$ & $\begin{array}{r}74 \\
\end{array}$ \\
\hline
\end{tabular}

*Months after discharge.

FIQ: Full scale IQ; VIQ: Verbal IQ; PIQ: Performance IQ; MQ Memory quotient; NT: not tested. oratory investigations.

Experimental study Case 1: Table 3 shows the Zpoint values and shows that patient R.M. initially had difficulty in naming all the stimuli presented either visually or verbally, and that such differences were more marked for animals and plants. The follow up examination at 18 months from discharge revealed that while naming of inanimate objects was normal, no significant improvement could be observed in naming animals and plants (Tests 1 and 4). In Test 2 (recognition upon presentation of visual stimuli), the results were the same as in the control group, except for slightly significant differences for plants on the first examination which disappeared at the next testing. In Test 3 (description upon presentation of verbal stimuli), the values were normal again, except for animals on the first examination with complete recovery at the next testing. Table 4 reports chi-square values and their significance comparing the results obtained for individual categories, that is objects vs animals, objects vs plants, and animals vs plants. This table is further proof that the deficits appeared to involve 


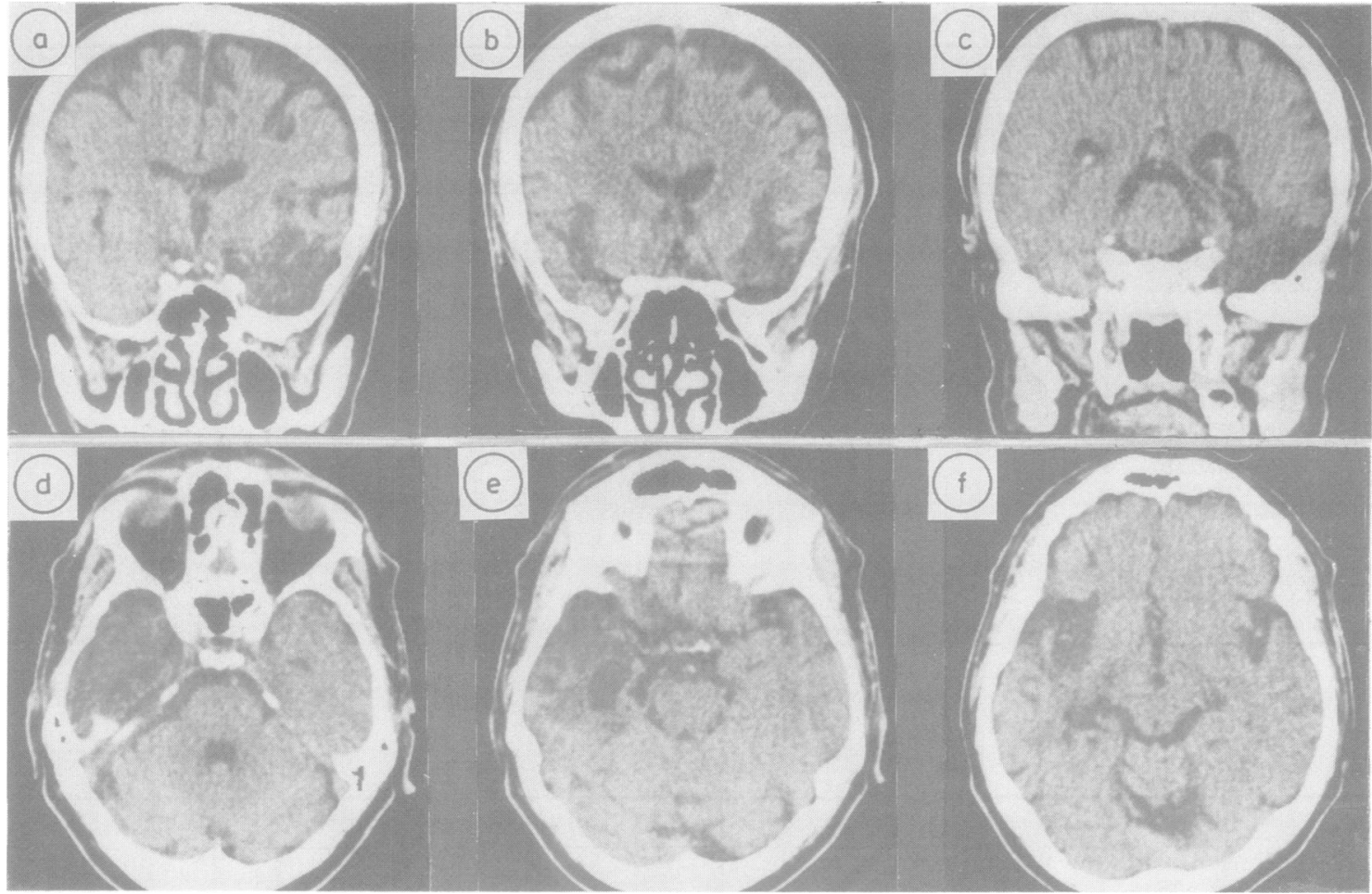

Fig 4 Case 2: serial CT one year after discharge. Low-absorption abnormality involving the left temporal lobe and the left-side insula.

Table 3 Experimental test

\begin{tabular}{|c|c|c|c|c|c|c|c|c|}
\hline & \multicolumn{8}{|c|}{$Z$-scores } \\
\hline & & & \multicolumn{6}{|c|}{ Case I } \\
\hline & \multicolumn{2}{|c|}{ Controls } & \multicolumn{3}{|c|}{$1^{\circ} \mathrm{Ex}$} & \multicolumn{3}{|c|}{$2^{\circ} E x$} \\
\hline & Mean & $S D$ & $R S$ & $z$ & $p$ & $R S$ & $z$ & $p$ \\
\hline $\begin{array}{l}\text { Test 1 } \\
\text { Objects } \\
\text { Animals } \\
\text { Plants }\end{array}$ & $\begin{array}{l}29 \\
28 \cdot 9 \\
28 \cdot 6\end{array}$ & $\begin{array}{l}1.05 \\
1.10 \\
1.26\end{array}$ & $\begin{array}{r}23 \\
11 \\
6\end{array}$ & $\begin{array}{r}-5 \cdot 71 \\
-16 \cdot 27 \\
-17.94\end{array}$ & $\begin{array}{l}<0.05 \\
<0.05 \\
<0.05\end{array}$ & $\begin{array}{r}28 \\
18 \\
9\end{array}$ & $\begin{array}{r}-0.95 \\
-9.91 \\
-15.55\end{array}$ & $\begin{aligned} & \text { NS } \\
< & 0.05 \\
< & 0.05\end{aligned}$ \\
\hline $\begin{array}{l}\text { Test } 2 \\
\text { Objects } \\
\text { Animals } \\
\text { Plants }\end{array}$ & $\begin{array}{l}30 \\
29 \\
28 \cdot 8\end{array}$ & $\begin{array}{l}0 \\
1 \cdot 15 \\
1 \cdot 23\end{array}$ & $\begin{array}{l}30 \\
28 \\
26\end{array}$ & $\begin{array}{l}\overline{-} \\
-0.87 \\
-2 \cdot 28\end{array}$ & $\begin{array}{c}\text { NS } \\
\text { NS } \\
<0.05\end{array}$ & $\begin{array}{l}30 \\
29 \\
27\end{array}$ & $\overline{-1 \cdot 46}$ & $\begin{array}{l}\text { NS } \\
\text { NS } \\
\text { NS }\end{array}$ \\
\hline $\begin{array}{l}\text { Test } 3 \\
\text { Objects } \\
\text { Animals } \\
\text { Plants }\end{array}$ & $\begin{array}{l}29 \cdot 1 \\
28 \cdot 6 \\
27\end{array}$ & $\begin{array}{l}1.10 \\
1.35 \\
1.63\end{array}$ & $\begin{array}{l}29 \\
17 \\
25\end{array}$ & $\begin{array}{l}-0.09 \\
-8.59 \\
-1.23\end{array}$ & $\begin{array}{c}\text { NS } \\
<0.05 \\
\text { NS }\end{array}$ & $\begin{array}{l}29 \\
27 \\
27\end{array}$ & $\begin{array}{l}-0.09 \\
-1 \cdot 18 \\
-\end{array}$ & $\begin{array}{l}\text { NS } \\
\text { NS } \\
\text { NS }\end{array}$ \\
\hline $\begin{array}{c}\text { Test } 4 \\
\text { Objects } \\
\text { Animals } \\
\text { Plants }\end{array}$ & $\begin{array}{l}29 \\
28 \cdot 5 \\
27\end{array}$ & $\begin{array}{l}1.09 \\
1.3 \\
1.3\end{array}$ & $\begin{array}{r}24 \\
10 \\
5\end{array}$ & $\begin{array}{r}-4.59 \\
-14.23 \\
-16.92\end{array}$ & $\begin{array}{l}<0.05 \\
<0.05 \\
<0.05\end{array}$ & $\begin{array}{l}28 \\
16 \\
10\end{array}$ & $\begin{array}{r}-0.92 \\
-9.61 \\
-13.08\end{array}$ & $\begin{aligned} & N S \\
< & 0.05 \\
< & 0.05\end{aligned}$ \\
\hline
\end{tabular}

NS = not significant; $R S$ = raw scores; Ex = examination; $S D=$ standard deviation. 
Table 4 Experimental test

\begin{tabular}{|c|c|c|c|c|}
\hline & \multicolumn{4}{|c|}{ Case 1: Chi-square values } \\
\hline & \multicolumn{2}{|l|}{$I^{\circ} E x$} & \multicolumn{2}{|l|}{$2^{\circ} E x$} \\
\hline & $C h i^{2}$ & $p$ & $C h i^{2}$ & $p$ \\
\hline $\begin{array}{l}\text { Test } 1 \\
\text { Objects vs animals } \\
\text { Objects vs plants } \\
\text { Animals vs plants }\end{array}$ & $\begin{array}{r}9 \cdot 77 \\
19.28 \\
2.05\end{array}$ & $\begin{array}{c}<0.05 \\
<0.05 \\
\text { NS }\end{array}$ & $\begin{array}{r}9 \cdot 31 \\
25 \cdot 45 \\
5 \cdot 45\end{array}$ & $\begin{array}{c}<0.05 \\
<0.05 \\
\text { NS }\end{array}$ \\
\hline $\begin{array}{l}\text { Test } 2 \\
\text { Objects vs animals } \\
\text { Objects vs plants } \\
\text { Animals vs plants }\end{array}$ & $\begin{array}{l}2.06 \\
4 \cdot 28 \\
0.74\end{array}$ & $\begin{array}{c}\text { NS } \\
<0.05 \\
\text { NS }\end{array}$ & $\begin{array}{l}1.01 \\
3.15 \\
1.07\end{array}$ & $\begin{array}{l}\text { NS } \\
\text { NS } \\
\text { NS }\end{array}$ \\
\hline $\begin{array}{l}\text { Test } 3 \\
\text { Objects vs animals } \\
\text { Objects vs plants } \\
\text { Animals vs plants }\end{array}$ & $\begin{array}{c}13.4 \\
2.96 \\
5.07\end{array}$ & $\begin{array}{c}<0.05 \\
\text { NS } \\
<0.05\end{array}$ & $\begin{array}{l}1.07 \\
1.07 \\
0\end{array}$ & $\begin{array}{l}\text { NS } \\
\text { NS } \\
\text { NS }\end{array}$ \\
\hline $\begin{array}{l}\text { Test } 4 \\
\text { Objects vs animals } \\
\text { Objects vs plants } \\
\text { Animals vs plants }\end{array}$ & $\begin{array}{c}13 \cdot 30 \\
24 \\
2 \cdot 22\end{array}$ & $\begin{array}{c}<0.05 \\
<0.05 \\
\text { NS }\end{array}$ & $\begin{array}{r}12 \cdot 27 \\
23 \cdot 25 \\
2 \cdot 14\end{array}$ & $\begin{array}{l}<0.05 \\
<0.05 \\
\text { NS }\end{array}$ \\
\hline
\end{tabular}

Ex = examination; $\mathrm{NS}=$ not significant.

Table 5 Experimental test

\begin{tabular}{|c|c|c|c|c|c|c|c|c|c|c|c|}
\hline & \multicolumn{11}{|c|}{ Z-scores } \\
\hline & & & Case & & & & & & & & \\
\hline & \multicolumn{2}{|c|}{ Controls } & \multicolumn{3}{|c|}{$I^{\circ} E x$} & \multicolumn{3}{|c|}{$2^{\circ} E x$} & \multicolumn{3}{|c|}{$3^{\circ} E x$} \\
\hline & Mean & $S D$ & $R S$ & $z$ & $p$ & $R S$ & $z$ & $p$ & $R S$ & $z$ & $p$ \\
\hline $\begin{array}{c}\text { Test } 1 \\
\text { Objects } \\
\text { Animals } \\
\text { Plants }\end{array}$ & $\begin{array}{l}29 \\
28 \cdot 9 \\
28 \cdot 6\end{array}$ & $\begin{array}{l}1.05 \\
1.10 \\
1.26\end{array}$ & $\begin{array}{r}14 \\
8 \\
4\end{array}$ & $\begin{array}{l}-14.28 \\
-19 \\
-19.52\end{array}$ & $\begin{array}{l}<0.05 \\
<0.05 \\
<0.05\end{array}$ & $\begin{array}{r}22 \\
15 \\
7\end{array}$ & $\begin{array}{r}-6.67 \\
-12.64 \\
-17.14\end{array}$ & $\begin{array}{l}<0.05 \\
<0.05 \\
<0.05\end{array}$ & $\begin{array}{r}23 \\
16 \\
7\end{array}$ & $\begin{array}{r}-6.67 \\
-11.73 \\
-17.14\end{array}$ & $\begin{array}{l}<0.05 \\
<0.05 \\
<0.05\end{array}$ \\
\hline $\begin{array}{l}\text { Test } 2 \\
\text { Objects } \\
\text { Animals } \\
\text { Plants }\end{array}$ & $\begin{array}{l}30 \\
29 \\
28 \cdot 8\end{array}$ & $\begin{array}{l}0 \\
1 \cdot 15 \\
1.23\end{array}$ & $\begin{array}{l}30 \\
24 \\
13\end{array}$ & $\begin{array}{c}0 \\
-4.35 \\
-12.84\end{array}$ & $\begin{aligned} & \text { NS } \\
&< 0.05 \\
&<0.05\end{aligned}$ & $\begin{array}{l}30 \\
26 \\
20\end{array}$ & $\begin{array}{c}0 \\
-2 \cdot 61 \\
-7 \cdot 15\end{array}$ & $\begin{aligned} & \text { NS } \\
< & 0.05 \\
< & 0.05\end{aligned}$ & $\begin{array}{l}30 \\
28 \\
21\end{array}$ & $\begin{array}{c}0 \\
-0.87 \\
-6 \cdot 34\end{array}$ & $\begin{array}{c}\text { NS } \\
\text { NS } \\
<0.05\end{array}$ \\
\hline $\begin{array}{c}\text { Test } 3 \\
\text { Objects } \\
\text { Animals } \\
\text { Plants }\end{array}$ & $\begin{array}{l}29 \cdot 1 \\
28 \cdot 6 \\
27\end{array}$ & $\begin{array}{l}1.10 \\
1.35 \\
1.63\end{array}$ & $\begin{array}{l}27 \\
19 \\
11\end{array}$ & $\begin{array}{l}-1.91 \\
-7 \cdot 11 \\
-9.81\end{array}$ & $\begin{array}{l}<0.05 \\
<0.05 \\
<0.05\end{array}$ & $\begin{array}{l}29 \\
24 \\
16\end{array}$ & $\begin{array}{l}-0.09 \\
-3.41 \\
-6.75\end{array}$ & $\begin{aligned} & \text { NS } \\
< & 0.05 \\
< & 0.05\end{aligned}$ & $\begin{array}{l}29 \\
25 \\
16\end{array}$ & $\begin{array}{l}-0.09 \\
-2.67 \\
-6.75\end{array}$ & $\begin{aligned} & \text { NS } \\
< & 0.05 \\
< & 0.05\end{aligned}$ \\
\hline $\begin{array}{l}\text { Test } 4 \\
\text { Objects } \\
\text { Animals } \\
\text { Plants }\end{array}$ & $\begin{array}{l}29 \\
28 \cdot 5 \\
27\end{array}$ & $\begin{array}{l}1.09 \\
1.3 \\
1.3\end{array}$ & $\begin{array}{r}18 \\
11 \\
5\end{array}$ & $\begin{array}{l}-10.09 \\
-13.46 \\
-16.92\end{array}$ & $\begin{array}{l}<0.05 \\
<0.05 \\
<0.05\end{array}$ & $\begin{array}{r}22 \\
13 \\
7\end{array}$ & $\begin{array}{r}-6.42 \\
-11.92 \\
-15.38\end{array}$ & $\begin{array}{l}<0.05 \\
<0.05 \\
<0.05\end{array}$ & $\begin{array}{r}22 \\
13 \\
7\end{array}$ & $\begin{array}{r}-6.42 \\
-11.92 \\
-15.38\end{array}$ & $\begin{array}{l}<0.05 \\
<0.05 \\
<0.05\end{array}$ \\
\hline
\end{tabular}

NS = not significant; $R S=$ raw scores; $E x=$ examination; $S D=$ standard deviation.

specific categories only on naming tests. In summary, a selective anomic deficit was present for animals and plants when the items were presented visually and verbally.

Case 2 Table 5 shows the $Z$ values. The patient had difficulty in naming all three categories both with visual and with verbal stimuli. Scores were significant also at the third examination 19 months after discharge. In the recognition test, the deficit involved animals and plants at the two first examinations and plants only at the last examination. In the description test, the deficit involved both animals and plants. Table 6 shows the chi-square distribution and confirms the presence of a selective impairment for the 


\begin{tabular}{|c|c|c|c|c|c|c|}
\hline & \multicolumn{6}{|c|}{ Case 2: Chi-square values } \\
\hline & \multicolumn{2}{|l|}{$I^{\circ} E x$} & \multicolumn{2}{|l|}{$2^{\circ} E x$} & \multicolumn{2}{|l|}{$3^{\circ} E x$} \\
\hline & $C h i^{2}$ & $p$ & $C h i^{2}$ & $p$ & $C h i^{2}$ & $p$ \\
\hline $\begin{array}{l}\text { Test } 1 \\
\text { Objects vs animals } \\
\text { Objects vs plants } \\
\text { Animals vs plants }\end{array}$ & $\begin{array}{l}2.58 \\
7.93 \\
1.66\end{array}$ & $\begin{array}{c}\text { NS } \\
<0.05 \\
\text { NS }\end{array}$ & $\begin{array}{r}3.45 \\
15.01 \\
4.59\end{array}$ & $\begin{array}{c}\text { NS } \\
<0.05 \\
<0.05\end{array}$ & $\begin{array}{r}2.58 \\
15.01 \\
5.71\end{array}$ & $\begin{array}{c}\text { NS } \\
<0.05 \\
<0.05\end{array}$ \\
\hline $\begin{array}{l}\text { Test } 2 \\
\text { Objects vs animals } \\
\text { Objects vs plants } \\
\text { Animals vs plants }\end{array}$ & $\begin{array}{r}6.66 \\
23 \cdot 72 \\
8 \cdot 53\end{array}$ & $\begin{array}{l}<0.05 \\
<0.05 \\
<0.05\end{array}$ & $\begin{array}{r}4 \cdot 28 \\
12 \cdot 00 \\
3 \cdot 35\end{array}$ & $\begin{array}{c}<0.05 \\
<0.05 \\
\text { NS }\end{array}$ & $\begin{array}{r}2.06 \\
10.58 \\
5.45\end{array}$ & $\begin{array}{c}\text { NS } \\
<0.05 \\
<0.05\end{array}$ \\
\hline $\begin{array}{l}\text { Test } 3 \\
\text { Objects vs animals } \\
\text { Objects vs plants } \\
\text { Animals vs plants }\end{array}$ & $\begin{array}{r}5.96 \\
18.37 \\
4.26\end{array}$ & $\begin{array}{l}<0.05 \\
<0.05 \\
<0.05\end{array}$ & $\begin{array}{r}4.04 \\
15.02 \\
4.08\end{array}$ & $\begin{array}{l}<0.05 \\
<0.05 \\
<0.05\end{array}$ & $\begin{array}{r}2.96 \\
15 \cdot 02 \\
6 \cdot 23\end{array}$ & $\begin{array}{c}\text { NS } \\
<0.05 \\
<0.05\end{array}$ \\
\hline $\begin{array}{l}\text { Test } 4 \\
\text { Objects vs animals } \\
\text { Objects vs plants } \\
\text { Animals vs plants }\end{array}$ & $\begin{array}{r}3.27 \\
11.91 \\
3.00\end{array}$ & $\begin{array}{c}\text { NS } \\
<0.05 \\
\text { NS }\end{array}$ & $\begin{array}{r}5.55 \\
15.00 \\
2.70\end{array}$ & $\begin{array}{c}<0.05 \\
<0.05 \\
\text { NS }\end{array}$ & $\begin{array}{r}5.55 \\
15.00 \\
2.70\end{array}$ & $\begin{array}{c}<0.05 \\
<0.05 \\
\quad \text { NS }\end{array}$ \\
\hline
\end{tabular}

Ex = examination; NS = not significant.

plants category. Unlike Case 1, the patient's performances were poorer for animals than for inanimate objects but the difference between these two categories was not statistically significant, except in Test 4 (naming from description).

In summary, difficulty in naming upon presentation of both visual and verbal stimuli for all categories appeared to persist over time, as well as difficulty in

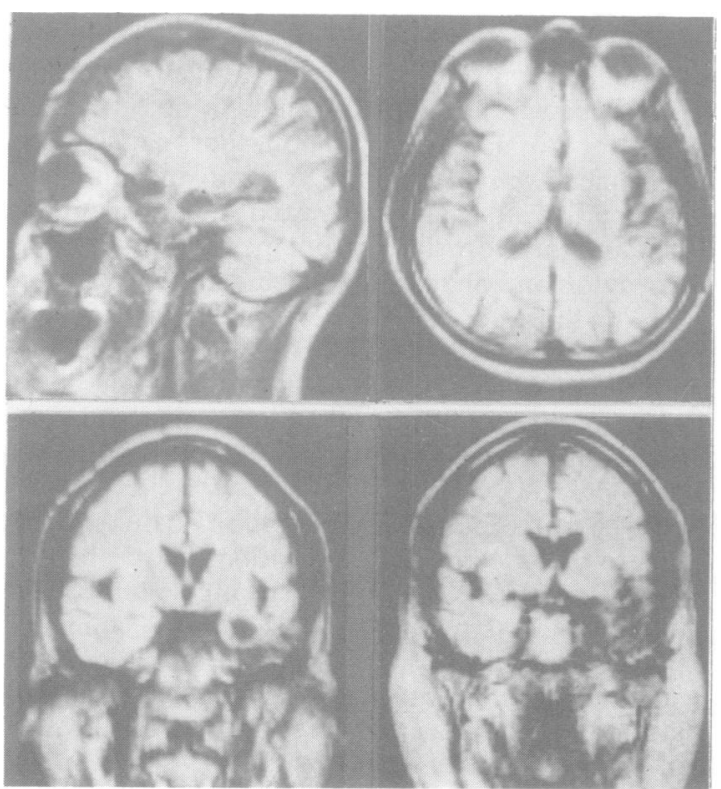

Fig 5 Case 2 MRI: the most affected areas are the leftside insula and the left temporal lobe. A mild involvement is also evident in the right-side insula. verbal description for animals and plants and in recognition for plants only. The latter category appeared to be the most affected in all tests.

\section{Discussion}

Cerebral biopsy is generally considered the best method for rapid diagnosis of herpes simplex encephalitis. ${ }^{15-17}$ However, in the absence of brain biopsy which is not always feasible for technical or ethical reasons, diagnosis of herpes simplex encephalitis can be made by means of serological tests, that is by detecting herpes simplex specific antibody in the patient's serum and CSF. ${ }^{418}$ In particular, a diagnosis of herpes simplex encephalitis is made when the serum to CSF herpes simplex specific antibody ratio is $\leqslant 20: 1$, which can be attributed to intrathecal production. ${ }^{19}$ Our patients satisfied these serologic criteria and also had clinical histories and neuroradiological findings typical of herpes simplex encephalitis.

The purpose of this paper is (1) to investigate the restoration of mental functions in patients with HSV1 encephalitis in order to determine which deficits persist and which functions are restored over time; and (2) to compare the residual neuropsychological deficits in the two patients with the anatomical lesions observed by neuroradiological investigation in order to evaluate the functional role of the brain structures affected by herpes simplex infection.

The general neuropsychological testing showed a good recovery of the higher cortical functions, which had been severely impaired in both patients. About 18 months after the acute stage, their scores fell within the medium range of the WAIS and they were able to 
resume full work even though both still suffered from amnesia. An experimental test aimed at determining whether the patients' speech and memory impairment involved specific categories showed that differences actually existed between the two patients. In Case 1, aside from his general good recovery, anomia persisted over time for the categories of animals and plants. However, since the patient's speech abilities were intact, that is, there was no difficulty in articulation and comprehension, the length of the sentences was normal and so were syntax and grammar, the deficit was purely anomic in type. Anomia for specific categories has already been reported, ${ }^{50}$ but it is interesting to note that in our patients the categories involved were exactly the same as those reported by Warrington and Shallice ${ }^{8}$ in a similar study carried out on four patients with herpes simplex encephalitis. It seems that the deficits are highly specific for certain categories, which would suggest that, within extensive lesions, the virus is likely to prefer well-selected neuronal systems. As no phenomena were present which could be related to aphasia, such as paraphasia, "conduite d'approche", neologism and circumlocutions, while severe amnesia persisted and the lesions were located in the temporal region, the anomia found in the first patient can be regarded as a form of amnestic anomia.

The second patient showed great difficulty in naming both the visual and verbal items presented to him for all categories, but even more so for animals and plants. Since he also had difficulty in recognising stimuli belonging to the two last categories, the question arose whether his deficit could be not only anomic but also agnostic in type. If the recognition deficit had been related to visual agnosia, then the patient should have been able to name concepts belonging to the animals and plants categories described to him in detail by the examiner (naming from description). However, the patient's score in Test 4 was significantly below the normal range. The question also arose whether this test might have been invalidated by the patient's anomia, and the tests of description upon presentation of verbal stimuli (Test 3) was performed to solve any such doubts. Had the patient suffered either from visual agnosia or anomia, he should have been able to describe the concepts named by the examiner; on the contrary, his score was low on this test also. The results of the different tests ruled out the possibility of an agnostic deficit and revealed instead the presence of visual and verbal deficits of the semantic systems. A selective impairment of semantic memory could therefore be assumed.

Semantic memory is a system for storing information and concepts acquired since childhood which implies both visual and verbal knowledge. ${ }^{21-23} \mathrm{~A}$ deterioration of the information stored in the semantic system results in failure to recognise, describe, and name concepts. Aside from the differences found, some similarities did exist between our two patients, as proven by the naming tests in which both of them obtained far lower scores than in the other tests. With the second patient, too, the results of Tests 1 and 4 were poorer than those of Tests 2 and 3, confirming that a more marked naming deficit was added to the recognition and description deficits. Then the hypothesis may be advanced that, depending on the extent of the lesion, different functional "levels" may be involved, with only a disturbed recollection of the names of certain animals and plants (amnestic anomia) when a comparatively mild lesion is restricted to one hemisphere but with further deficits in recognition and description of the same concepts (impairment of semantic memory) when a more severe lesion spreads to the opposite hemisphere.

As far as the evolution of such deficits over time is concerned, the first patient showed a good recovery in all categories, which remained so in the period of time between 12 and 18 months after discharge. On the other hand in the second patient, after an initial good recovery during the first 12 months, a steady impairment resulting in an absolute response consistency from test to test and from session to session between 12 and 18 months after discharge was observed. This finding appears to support the hypothesis of a degradation of the semantic representation of the concepts. ${ }^{923}$

Our study confirms the observation of Warrington and Shallice ${ }^{8}$ on the selective impairment of specific semantic categories, namely "animate objects". It is interesting to note that in both our patients the involvement was more marked for plants than for animals. The first patient showed a purely anomic deficit and therefore differs from the cases reported by Warrington and Shallice, in which deficits were more similar to those of Case No. 2. The difference might be explained by the fact that in patient No. 1 the temporal lesion was unilateral and located in the dominant hemisphere while in the patients studied by the British authors the damage was bilateral, similar to case No. 2.

The neuroradiological investigation on our patients failed to provide any clear indications about the area or structures responsible for storing memory and naming concepts related to categories of "animated objects", the brain damage apparent on radiographs being much too extensive for a close anatomical correlation to be established. Our findings seem to suggest that a lesion of some neuronal systems in the inferior and middle temporal gyri, the hippocampal and parahippocampal regions, and the left-side insula may lead, in a right-handed subject, to a deficit 
resulting in anomia for certain semantic categories upon neuropsychological tests. When the damage spreads to the insula on the opposite side, a disturbance of the internal representation of the concepts related to the same categories may occur. Anatomopathological investigations carried out on large series of patients have shown a special affinity of herpes simplex for the same structures that were affected on our two cases. ${ }^{24-25}$ In particular, the virus seems to have a clear preference for the limbic system. Recently, neurons of the rat limbic system have been found to have antigens different from the adjoining areas $^{26}$ and the hypothesis has been advanced that the attack of herpes simplex and the vulnerability of the limbic system may be a consequence of this molecular specificity. ${ }^{27}$ In our opinion, further, if indirect, evidence of this assumption is provided by the selective nature of the neuropsychological damage and its tendency to repeat itself, just as happens with the anatomical damage.

We thank Professor Orazio Rossi for his help with the statistics and Miss Daniela Mirotti for secretarial assistance.

\section{References}

1 Boston Interhospital Virus Study group and the NIAID. Sponsored Cooperative Antiviral Clinical Study. Failure of high dose 5-iodo 2'-deoxyuride in the therapy of herpes simplex virus encephalitis: evidence of unacceptable toxicity. $N$ Engl J Med 1975;292:599-603.

2 Longson M. Le défi des encéphalitis herpétiques. Ann Inst Pasteur Microbiol (Paris) 1979:130-135.

3 Whitley RJ, Soong SJ, Dolin R, et al. Adenine arabinoside therapy of biopsy-proved herpes simplex encephalitis. N Engl J Med 1977;297:289-94.

4 Skoldesiberg B, Forgren M, Alestig K, et al. Acyclovir versus vidarabine in herpes simplex encephalitis. Randomized Multicentre Study in Consecutive Swedish Patients. Lancet 1984;ii:707-11.

5 Goodglass H, Klein B, Carey P, Jones K. Specific semantic word categories in aphasia. Cortex 1966;2:74-89.

6 Warrington E. The selective impairment of semantic memory. Q J Exp Psychol 1975;27:635-57.

7 Warrington E. Neuropsychological studies of verbal semantic systems. Phil Trans $R$ Soc Lond B 1981;295:411-23.
8 Warrington E, Shallice T. Category specific semantic impairments. Brain 1984;107:829-54.

9 Warrington E, McCarthy R. Category specific access dysphasia. Brain 1983;106:859-78.

10 Tibbling G, Link H, Ohman S. Principles of albumin and IgG analyses in neurological disorders. I. Establishment of reference value. Scand J Clin Lab Invest 1977;37:385-92.

11 Rosch E, Mervis CB, Gray WD, Johnson DM. Basic objects in natural categories. Cognitive Psychology 1976;8:382-439.

12 Davis JM, Davis KR, Kleinman GM, et al. Computed tomography of herpes simplex encephalitis, with clinicopathological correlation. Radiology 1978;129:409-17.

13 Enzmann DR, Ranson B, Norman D, Tolberth E. Computed tomography of herpes simplex encephalitis. Radiology 1978;129:419-25.

14 Kaufman DM, Zimmerman RD, Leeds NE. Computed tomog raphy in herpes simplex encephalitis. Neurology 1979; 29:1392-6.

15 Johnson RT, Olson LC, Bueschen EL. Herpes simplex virus infections of nervous system. Problems in laboratory diagnosis. Arch Neurol 1968;18:260-4.

16 Whitley RJ, Soong SJ, Hirsch MS, et al. Herpes simplex encephalitis. Vidarabine therapy and diagnostic problems. $N$ Engl J Med 1981;304:313-8.

17 Nahmias AJ, Whitley RJ, Visintin AN, et al. Herpes simplex virus encephalitis: laboratory evaluations and their diagnostic significance. J Infect Dis 1982;145:829-36.

18 Klapper PE, Laing I, Longson M. Rapid non-invasive diagnosis of herpes encephalitis. Lancet 1981;ii:607-8.

19 Koskiniemi M, Vacheri A, Taskinen E. Cerebrospinal fluid alterations in herpes simplex virus encephalitis. Rev Infect Dis 1984;6:608-18.

20 Benson DF. Neurologic correlates of anomia. In: Whitaker HA Whitaker HH, eds. Studies in Neurolinguistics. New York: Academic Press, 1979:293-328.

21 Tulving E. Episodic and semantic memory. In: Tulving E and Donaldson eds. Organization of Memory. New York: Academic Press 1972.

22 Rosch E. Cognitive representations of semantic categories. J Exp Psychol 1975;104:192-233.

23 Warrington E, Shellice T. Semantic access dyslexis. Brain 1979;102:43-63.

24 Adams H, Miller D. Herpes simplex encephalitis. A clinical and pathological analysis of 22 cases. Postgrad Med J $1973 ; 49: 393-7$.

25 Boringer JH. Herpes simplex infections of the nervous system. In: Winken P, Bruyn GW eds. Handbook of Clinical Neurology, Amsterdam: Elsevier, 1978;34:145-59.

26 Levitt P. A monoclonal antibody to limbic system nervous. Science 1984;223:299-301.

27 Damasio AR, Von Hoesen GW. The limbic system and the localization of herpes simplex encephalitis. $J$ Neurol Neurosurg Psychiatry 1985;48:297-301. 